\title{
USIA SEBAGAI FAKTOR RISIKO YANG PALING BANYAK DITEMUKAN PADA OBESITAS DI PUSKESMAS CIPTOMULYO KECAMATAN SUKUN KOTA MALANG
}

\author{
Wiwik Agustina, Ekawarsih Lampah \\ STIKes Maharani Malang \\ E-mail : nerswika@gmail.com
}

\begin{abstract}
Central obesity is a public health problem that can occur in the world. Central obesity is one of the causes of degenerative diseases such as type 2 diabetes mellitus, dyslipidemia, cardiovascular disease, hypertension, cancer, sleep apnea, and metabolic syndrome. Metabolic syndrome is a condition in which a person develops hypertension, central obesity, dyslipidemia, and insulin resistance at the same time. Degenerative diseases are influenced by many factors: age, physical activity, emotional mental state, nutrition and hormonal contraceptive use. This study aims to determine the determinant factors of central obesity. The study design used was descriptive explorative. The sample of research is 40 respondents. The selected sample corresponds to the inclusion criteria.Prevalence of central obesity in Sukun Kota Malang counted 40 respondents, with result almost all respondents $90 \%$ have age which is at risk of central obesity, physical activity almost half of respondents $53 \%$ have aktvitas physical and $47 \%$ have activity light, emotional mental condition most of respondent $65 \%$ have normal emotional mental condition, nutrition most respondents $63 \%$ have normal nutrition, and hormonal contraceptive use most of respondents $67 \%$ of hormonal contraceptive users. It was concluded that the most common risk factor in obese people in Puskesmas Ciptomulyo Kecamatan Sukun Kota Malang, was the age factor, so it can be suggested to the public to further increase physical activity, and switch to using non-hormonal contraception.
\end{abstract}

Key Word : central obesity, risk factor

Abstrak: Obesitas sentral merupakan masalah kesehatan masyarakat yang dapat terjadi di dunia. Obesitas sentral merupakan salah satu penyebab terjadinya penyakit - penyakit degeneratif seperti diabetes mellitus tipe 2, dyslipidemia, penyakit kardiovaskular, hipertensi, kanker, sleep apnea, dan sindrom metabolic. Sindrom metabolik adalah kondisi dimana seseorang mengalami hipertensi, obesitas sentral, dyslipidemia, dan resistensi insulin pada waktu yang bersamaan. Penyakit degenerative dipengaruhi oleh banyak faktor yaitu usia, aktivitas fisik, kondisi mental emosional, nutrisi dan penggunaan kontrasepsi hormonal. Penelitian ini bertujuan untuk mengetahui faktor determinan terjadinya obesitas sentral. Desain studi yang digunakan adalah deskriptif eksploratif. Sampel penelitian sebanyak 40 responden. Sampel yang dipilih sesuai dengan kriteria inklusi. Prevalensi obesitas sentral di Sukun Kota Malang sebanyak 40 responden, dengan hasil hampir seluruh responden $90 \%$ memiliki usia yang berisiko mengalami obesitas sentral, aktivitas fisik hampir setengah responden $53 \%$ memiliki aktvitas fisik sedang dan $47 \%$ memiliki aktivitas ringan, kondisi mental emosional sebagian besar responden $65 \%$ memiliki kondisi mental emosional normal, nutrisi sebagian besar responden $63 \%$ memiliki nutrisi normal, dan penggunaan kontrasepsi hormonal sebagian besar responden $67 \%$ pengguna kontrasepsi hormonal meningkat. Disimpulkan bahwa faktor risiko yang paling banyak ditemukan pada orang yang mengalami obesitas di Puskesmas Ciptomulyo Kecamatan Sukun Kota Malang adalah faktor usia dengan demikian dapat disarankan kepada masyarakat agar lebih aktivitas fisik, dan beralih menggunakan kontrasepsi yang tidak mengandung hormon.

Kata Kunci : obesitas sentral, faktor risiko

\section{PENDAHULUAN}

Obesitas sentral didefinisikan sebagai penumpukan lemak dalam tubuh bagian perut. Penumpukan lemak ini diakibatkan oleh jumlah lemak berlebih pada jaringan lemak subkutan dan lemak viseral perut. Penumpukan lemak pada jaringan lemak viseral merupakan bentuk dari tidak berfungsinya jaringan lemak subkutan dalam menghadapi ketidakseimbangan energi pada tubuh (Tchernof dan Depres, 2013). Ketidakseimbangan energi pada tubuh disebabkan oleh terjadinya peningkatan asupan gizi dan kurangnya aktivitas fisik. Beberapa faktor yang yang dapat menyebabkan terjadinya obesitas sentral 
ialah usia (Tchernof dan Despres, 2013). Usia merupakan faktor prediksi dari terjadinya obesitas sentral (Veghari dkk, 2010). Perubahan usia memiliki hubungan dengan terjadinya perubahan dalam komposisi tubuh seseorang. Pada usia 20-30 tahun diketahui terjadi penurunan pada massa jaringan bebas lemak dan peningkatan pada massa jaringan lemak (Tchernof dan Depres, 2013). Pada penelitian Bowen dkk (2015) menunjukan bahwa terdapat hubungan antara asupan energi, asupan lemak, dan asupan protein dengan obesitas sentral. Dalam penelitian tersebut diketahui bahwa sampel yang mengalami obesitas sentral memiliki asupan energi, asupan lemak, dan asupan protein yang tinggi. Penelitian Harikedua dan Naomi (2012), juga menunjukan bahwa asupan karbohidrat sederhana dan serat juga berhubungan dengan obesitas sentral. Pada penelitian tersebut diketahui bahwa seseorang mengalami obesitas sentral memiliki asupan tinggi karbohidrat sederhana dan asupan rendah serat.

Obesitas sentral berhubungan dengan kondisi mental emosional seseorang. Pada penelitian Sugianti dkk (2009), diketahui prevalensi obesitas sentral lebih tinggi pada sampel yang kondisi emosionalnya terganggu. Dalam penelitian tersebut juga menunjukkan bahwa sampel dengan kondisi emosional terganggu berisiko 1,135 kali obesitas sentral dibandingkan dengan sampel yang tidak memiliki gangguan mental emosional.

Aktivitas fisik juga berhubungan dengan terjadinya obesitas sentral. Aktivitas fisik yang rutin diketahui dapat mendorong penurunan yang cukup besar pada jaringan lemak tubuh dalam tubuh seseorang (Tchernof dan Despres, 2013). Pada penelitian Pujiati (2010) diketahui bahwa aktifitas fisik memiliki hubungan dengan obesitas sentral pada orang dewasa. Selain itu, pada penelitian Sugianti dkk (2009) menunjukan bahwa obesitas sentral lebih banyak terjadi pada seseorang yang tidak memiliki aktifitas berat.

Selain itu pemakaian kontrasepsi juga dapat meningkatkan berat badan disebabkan oleh hormon dalam kontrasepsi yaitu esterogen dan progesteron. Esterogen menyebabkan pengeluaran natriun dan air berkurang sehingga terjadi penimbunan cairan (Wiknjosastro dkk, 2005) sedangkan progesterone akan mempermudah perubahan karbohidrat dan gula menjadi lemak, merangsang nafsu makan serta menurunkan aktivitas fisik sehingga terjadi peningkatan berat badan (Depkes RI, 1994).

Obesitas sentral merupakan salah satu penyebab terjadinya penyakitpenyakit degeneratif, seperti diabetes mellitus tipe 2, dyslipidemia, penyakit kardiovaskular, hipertensi, kanker, sleep apnea, dan sindrom metabolik (Tchernof dan Desptes, 2013). Sindrom metabolik adalah kondisi dimana seseorang mengalami hipertensi, obesitas sentral, dyslipidemia, dan resistensi insulin pada waktu yang bersamaan (Gibney dkk, 2009). Kondisi obesitas sentral identik dengan kondisi kehamilan dimana pembesaran perut mendesak ruang diagfragma, sehingga menurunkan kemampuan ekspansi paru yang dapat menimbulkan gangguan pada sistem pernafasan, misalnya dapat meningkatkan frekuensi kekambuhan pasa penderita asma (Agustina, 2015).

Pada studi pendahuluan yang dilakukan peneliti pada bulan Desember 2016 di Sukun Kota Malang didapatkan hasil bahwa jumlah obesitas sentral pada wanita usia dewasa yang di dapat oleh peneliti dari petugas Puskesmas Ciptomulyo Kecamatan Sukun Kota Malang sebanyak 267 orang pada tiga bulan terakhir yang mengalami obesitas sentral atau lingkar pinggang $\geq 80 \mathrm{~cm}$. Berdasarkan fenomena di atas perlu dilakukan studi ekplorasi faktor-faktor risiko yang terdapat pada orang yang mengalami obesitas di Puskesmas Ciptomulyo Kecamatan Sukun Kota Malang.

\section{METODE}

Penelitian ini menggunakan metode deskriptif eksploratif. Populasi dalam penelitian ini adalah seluruh wanita obesitas sentral usia dewasa di Sukun Kota Malang, sebanyak 267 orang. Teknik sampling yang digunakan dalam penelitian ini adalah Accidental 
Sampling didapatkan sejumlah 40 responden. Instrumen untuk mengukur variabel faktor-faktor yang mempengaruhi obesitas sentral yaitu:

a) Usia

Usia menggunakan satuan waktu yang diperoleh melalui lembar kuesioner kepada responden.

b) Aktivitas Fisik

Aktivitas fisik pada penelitian ini menggunakan kuesioner IPAQ short forms.

c) Kondisi Mental Emosional

Pada penelitian ini diukur menggunakan lembar kuesioner Self Reporting Questionnaire (SRQ).

d) Nutrisi

Nutrisi diukur menggunakan kuesioner food recall. Food recall yang digunakan ialah food recall 1x24 jam.

e) Penggunaan Alat Kontrasepsi Hormonal Data penggunaan alat kontrasepsi hormonal diperoleh dengan cara wawancara langsung dengan menggunakan lembar kuesioner

f) Obesitas sentral

Obesitas sentral dilakukan pengukuran pada lingkar pinggang responden. Alat ukur yang digunakan ialah pita ukur seca dengan ketelitian $0,1 \mathrm{~cm}$.

Analisis data yang digunakan adalah analisis deskriptif menggunakan prosentase

\section{HASIL PENELITIAN}

Penelitian dilaksanakan di Sukun Kota Malang pada bulan Februari - Mei 2017. Dari hasil analisa didapatkan bahwa kejadian obesitas sentral di Sukun Kota Malang sebanyak 40 responden dengan lingkar pinggang $>80 \mathrm{~cm}$. Dari 40 responden yang mengalami obesitas sentral selanjutnya akan dilihat faktorfaktor risiko yang mempengaruhi kejadian obesitas sentral.

\section{Distribusi frekuensi responden berdasarkan usia}

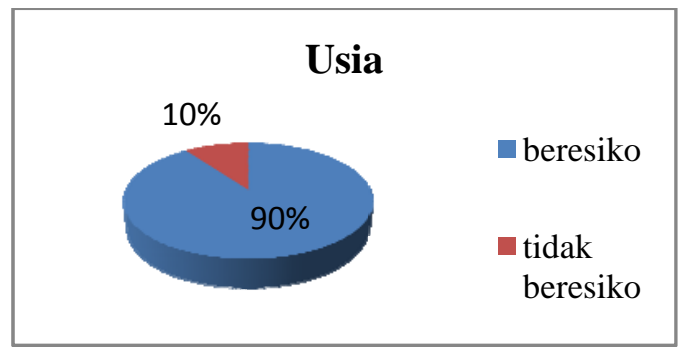

Gambar 1. Distribusi frekuensi berdasarkan usia

Berdasarkan pada Gambar 5.2 distribusi frekuensi diatas diketahui bahwa hampir seluruh responden $(90 \%)$ memiliki usia yang berisiko mengalami obesitas sentral.

\section{Distribusi frekuensi responden berdasarkan aktifitas fisik}

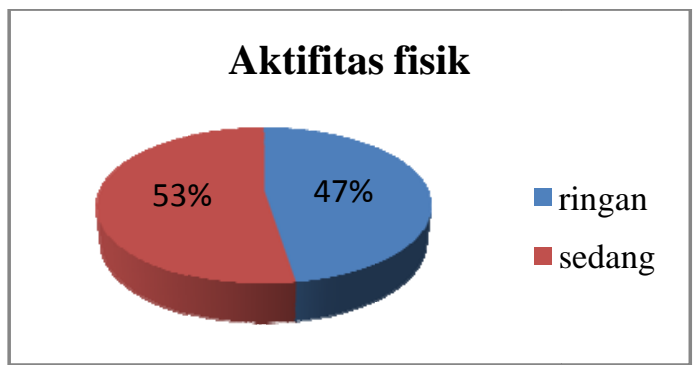

Gambar 2. Distribusi frekuensi berdasarkan aktivitas fisik

Berdasarkan pada Gambar 5.3 distribusi frekuensi diatas diketahui hampir setengah responden $(53 \%)$ memiliki aktvitas fisik sedang dan (47\%) memiliki aktivitas ringan. 
3. Distribusi frekuensi responden berdasarkan kondisi mental emosional.

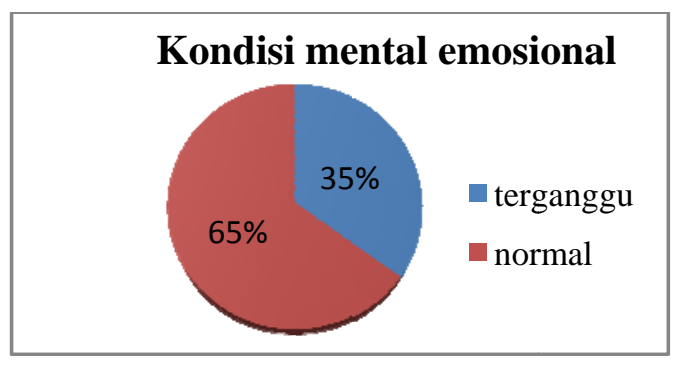

Gambar 3. Distribusi frekuensi berdasarkan kondisi mental emosional

Berdasarkan pada Gambar 5.4 distribusi frekuensi diatas diketahui bahwa sebagian besar responden $(65 \%)$ memiliki kondisi mental emosional normal.

4. Distribusi frekuensi responden berdasarkan nutrisi.

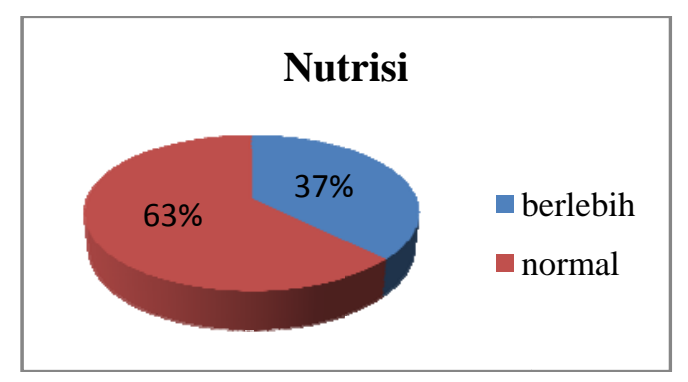

Gambar 4. Distribusi frekuensi berdasarkan nutrisi

Berdasarkan pada Gambar 5.5 distribusi frekuensi diatas diketahui bahwa sebagian besar responden (63\%) memiliki nutrisi normal.

5. Distribusi frekuensi responden berdasarkan penggunaan kontrasepsi hormonal.

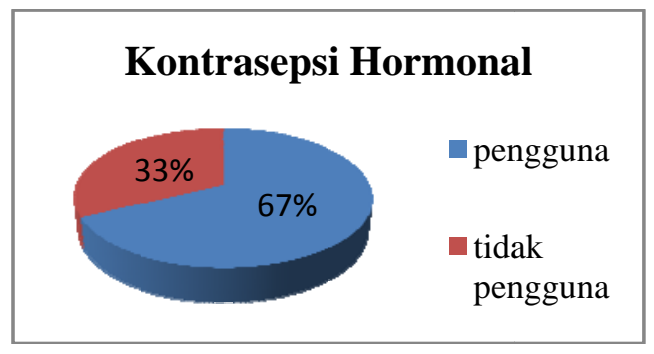

Gambar 5. Distribusi frekuensi berdasarkan penggunaan kontrasepsi hormonal

Berdasarkan Gambar 5.6 distribusi frekuensi diatas diketahui sebagian besar responden $(67 \%)$ pengguna kontrasepsi hormonal.

\section{PEMBAHASAN}

Hasil analisa tentang faktor-faktor yang mempengaruhi kejadian obesitas sentral di Sukun Kota Malang. Dari 40 responden, didapatkan data bahwa hampir seluruh responden $(90 \%)$ memiliki usia berisiko mengalami obesitas sentral dan yang tidak berisiko mengalami obesitas sentral yaitu (10\%). Obesitas sentral lebih banyak terjadi pada orang dewasa dimana, semakin meningkat umur, maka semakin tinggi risiko terjadinya obesitas sentral. Usia merupakan faktor prediksi dari terjadinya obesitas sentral (Veghari dkk, 2010). Perubahan umur berkaitan dengan peningkatan distribusi jaringan lemak yang di tandai dengan meningkatnya ukuran lingkar pinggang seseorang (Tchernof dan Despres, 2013). Selain itu, perubahan umur juga diketahui memiliki hubungan dengan 
terjadinya perubahan dalam komposisi tubuh, dimana pada usia 20-30 tahun terjadi penurunan pada massa bebas lemak dan peningkatan pada massa lemak.Hal ini sesuai dengan hasil penelitian yang peneliti lakukan di Sukun Kota Malang menunjukan bahwa faktor usia yang berisiko mengalami obesitas sentral sangat tinggi yaitu $90 \%$.

Pemeriksaan aktifitas fisik didapatkan data bahwa sebagian besar responden (53\%) memiliki aktfitas fisik sedang dan yang memiliki aktivitas ringan yaitu (47\%). Aktivitas fisik adalah setiap pergerakan tubuh yang ditimbulkan oleh otot-otot skeletal dan mengakibatkan pengeluaran energi (Gibney dkk, 2009). Aktifitas fisik atau olahraga yang rutin dapat mendorong penurunan yang cukup besar pada jaringan lemak, bahkan tanpa adanya penurunan berat badan (Tchernof dan Despres, 2013). Hal ini dikarenakan olahraga dapat meningkatkan masa jaringan bebas lemak. Pada penelitian Sugianti dkk (2009) juga menujukan bahwa ada hubungan negatif antara aktivitas fisik berat dengan obesitas sentral, dimana orang yang tidak memiliki aktivitas fisik berat, mengalami obesitas sentral sebesar $26,4 \%$ dan orang yang melakukan aktivitas fisik berat mengalami obesitas sentral sebesar $18 \%$. Hal ini sesuai dengan hasil penelitian yang peneliti lakukan di Sukun Kota Malang menunjukan bahwa faktor aktifitas fisik juga mempengaruhi seseorang mengalami obesitas sentral dimana pada penelitian ini tidak ditemukan responden dengan aktifitas berat.

Hasil pemeriksaan mental emosional sebagian besar responden (65\%) memiliki kondisi mental emosional normal dan yang terganggu yaitu (35\%). Gangguan mental emosional merupakan suatu keadaan yang mengindikasikan individu mengalami suatu perubahan emosional yang dapat berkembang menjadi keadaan patologis (Indaiani dkk, 2009). Stress merupakan akumulasi dari berbagai gejala gangguan mental emosional (Idaiani dkk, 2009) Stres diketahui berhubungan dengan obesitas sentral karena stress dapat mempengaruhi kebiasaan makan seseorang. Hubungan kebiasaan makan seseorang dengan stress dipengaruhi oleh jenis stress. Apabila seseorang mengalami stress akut, maka akan terjadi perubahan psikologis pada orang tersebut, dimana hal ini dapat menurunkan asupan makannya dalam jangka pendek. Sedangkan apabila seseorang mengalami stress kronik, maka akan menimbulkan respon pada kelenjar pituitary untuk meningkatkan produksi kortisol (Torres dan Caryl, 2007). Peningkatan kortisol ini dapat mempengaruhi kerja otak. Seseorang yang mengalami stress akan mengirimkan stimulus ke otak dan kemudian otak mengirimkan sinyal ke tubuh untuk meningkatkan nafsu makan (Purnamasari, 2013). Hal ini tidak sepenuhnya sesuai dengan hasil penelitian yang peneliti lakukan di Sukun Kota Malang menunjukan bahwa faktor kondisi mental emosional sebagian besar normal dibandingkan dengan yang terganggu.

Hasil pemeriksaan nutrisi didapatkan data bahwa sebagian besar responden $(63 \%)$ memiliki nutrisi normal dan yang belebih yaitu (37\%). Obesitas terjadi karena adanya ketidakseimbangan antara energi yang masuk dengan energi yang keluar dan merupakan akumulasi simpanan energi yang berubah menjadi lemak (Pritasari, 2006). Energi merupakan hasil dari metabolisme karbohidrat, lemak, dan protein (Pujiati, 2010). Manusia membutuhkan energi untuk melakukan metabolisme, pengaturan suhu tubuh, pertumbuhan dan aktivitas fisik (Almatsier, 2010). Pada penelitian Bowen dkk (2006), diketahui bahwa responden yang mengalami obesitas sentral pada penelitian tersebut memiliki asupan energi yang tinggi. Akan tetapi, hasil pelitian tersebut berbeda dengan penelitian Jaime dkk (2006), dimana tidak ada hubungan antara asupan energi dengan obesitas sentral. Dalam penelitian tersebut diketahui bahwa sampel yang memiliki asupan tinggi energi ialah responden yang tidak mengalami obesitas sentral. Hal ini tidak sepenuhnya sesuai dengan hasil penelitian yang peneliti lakukan di Sukun Kota Malang menunjukan bahwa faktor nutrisi sebagian besar normal dibandingkan dengan yang lebih.

Penggunaan kontrasepsi hormonal didapatkan data sebagian besar responden $(67 \%)$ pengguna kontrasepsi hormonal dan yang tidak pengguna yaitu (33\%). Maksud dari kontrasepsi adalah untuk menghindari atau mencegah terjadinya 
kehamilan sebagai akibat pertemuan antara sel telur yang telah matang dengan sel sperma (Depkes RI, 1994). Hubungan antara kontrasepsi dengan obesitas adalah peningkatan berat badan pada pemakaian kontrasepsi disebabkan hormon dalam kontrasepsi yaitu esterogen dan progesteron. Esterogen menyebabkan pengeluaran natriun dan air berkurang sehingga terjadi penimbunan cairan (Wiknjosastro dkk, 2005) sedangkan progesteron akan mempermudah perubahan karbohidrat dan gula menjadi lemak, merangsang nafsu makan serta menurunkan aktivitas fisik sehingga terjadi peningkatan berat badan (Depkes RI, 1994). Hal ini sesuai dengan hasil penelitian yang peneliti lakukan di Sukun Kota Malang menunjukan

\section{DAFTAR PUSTAKA}

Agustina, W. 2015. Respon Imun Pada Penderita Asma Selama Kehamilan. Jurnal IImu Kesehatan. Vol 2. No 1,p. 58-66. www.akperakbid-kediri.com/jurnal-akper

Almatsier, S. 2010. Prinsip Dasar Ilmu Gizi. Jakarta: PT Gramedia Pustaka

Bowen, Liza dkk. 2015. Associations between diet, phsical activity and body fat distribution: a cross sectional study in an Indian population. BMC Public Health, 15: 281

Depkes RI. 1994. Buku Pedoman Petugas Fasilitas Pelayanan Keluarga Berencana. Jakarta : Departemen Kesehatan Republik Indonesia Direktorat Jenderal Pembinaan Kesehatan Masyarakat Direktorat Bina Kesehatan Kelurga.

Gibney, Michael, J, dkk. 2009. Gizi Kesehatan Masyarakat. Jakarta:EGC

Harikedua. Veri T. dan Naomi M. Tando. 2012. Aktivitas Fisik Dan Pola Makan Dengan Obesitas Sentral Pada Toko Agama Di Kota Manado. Gizido. 4:1

Indaiani, Sri, Suhardi, dan Antonius Yudi Kristanto. 2009. Analisis Gejala Gangguan Mental Emosional Penduduk Indonesia. Majalah Kedokteran. Vol. 59.No.10

Jaime, Patricia Constante dkk. 2006. Central obesity and dietary intake bahwa faktor penggunaan kontrasepsi hormonal juga mempengaruhi seseorang mengalami obesitas sentral.

\section{KESIMPULAN DAN SARAN}

Kesimpulan dalam penelitian ini adalah faktor risiko yang banyak ditemukan pada orang yang mengalami obesitas di Puskesmas Ciptomulyo Kecamatan Sukun Kota Malang adalah usia. Oleh karena usia merupakan faktor risiko yang tidak bisa dimodifikasi maka diharapakan meminimalkan faktor risiko lain yang dapat dimodifikasi melalui peningkatan aktifitas fisik, kemampuan mengendalikan emosi, menyeimbangkan nutrisi dan menggunakan kontrasepsi non hormonal.

in HIVIAIDS patients. Rev Saude Publica, 40 (4):634-40.

Pritasari. 2006. Hidup Sehat Gizi Seimbang dalam Siklus Kehidupan Manusia. Jakarta : Primadia Pustaka IKAPI

Pujiati, S. 2010. Prevalensi Dan Faktor Risiko Obesitas Sentral Pada Penduduk Dewasa Kota Dan Kabupaten Indonesia Tahun 2007. Program Pasca Sarjana. Universitas Indonesia.

Purnamasari, Rita, Saifuddin Sirajuddin, dan Ulfah Najamuddin. 2013. Hubungan Pengetahuan, Status Merokok Dan Gejala Stres Dengan Kejadian Obesitas Sentral Pada Pegawai Pemerintahan Di Kantor Bupati Kabupaten Jeneponto. Jurnal Universitas Hasanuddin.

Sugianti, E., Hardiansyah dan Afriansyah, N.2009. Faktor Risiko Obesitas Sentral Pada Orang Dewasa Di DKI Jakarta: Analisis Lanjut Data Riskerdas 2007. Gizi Indonesia. $32: 2$

Tchernof, A dan Depres, J. P. 2013. Pathophysiology Of Human Visceral Obesity. Physiol Rev.93.

Veghari, G. Sedaghat, M. Joshaghani, H., dkk. 2010. The Prevalence And Associated Factors Of Central Obesity In Northern Iran Iranian Cardiovascular Research Journal. 4: 